\title{
Effectiveness and Transmission of the ECB's Balance Sheet Policies*
}

\author{
Jef Boeckx, ${ }^{\mathrm{a}}$ Maarten Dossche, ${ }^{\mathrm{b}}$ and Gert Peersman ${ }^{\mathrm{c}}$

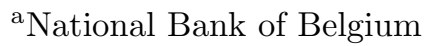 \\ ${ }^{\mathrm{b}}$ European Central Bank \\ ${ }^{\mathrm{c}}$ Ghent University
}

We estimate the effects of exogenous innovations to the balance sheet of the ECB since the start of the financial crisis within a structural VAR framework. An expansionary balance sheet shock stimulates bank lending, reduces interest rate spreads, leads to a depreciation of the euro, and has a positive impact on economic activity and inflation. A counterfactual analysis reveals that the macroeconomic consequences of the balance sheet policies in the aftermath of the crisis have been substantial. For example, euro-area output and inflation would have been more than 1 percent lower in 2012 without the threeyear LTRO programs. Finally, we find that the effects on output turn out to be smaller in the member countries that have been more affected by the financial crisis, in particular those countries where the banking system is less well capitalized.

JEL Codes: C32, E30, E44, E51, E52.

\section{Introduction}

There is a large literature that has used structural vector autoregressive (SVAR) models to examine the macroeconomic effects of changes in policy-controlled interest rates (e.g., Bernanke and Blinder 1992; Bernanke and Mihov 1998; Christiano, Eichenbaum,

${ }^{*}$ We would like to thank two anonymous referees, Luc Aucremanne, Pierpaolo Benigno (editor), Hugues Famerée, Pelin Ilbas, Raf Wouters, seminar participants at Hamburg University and the National Bank of Belgium, and participants at the "ECB Workshop on Non-standard Monetary Policies" for helpful comments. Special thanks to our discussant Luca Benati at the ECB workshop. The views expressed in this paper are those of the authors and do not necessarily reflect those of the National Bank of Belgium, the European Central Bank, or the Eurosystem. 
and Evans 1999; Peersman and Smets 2003). VAR models are reduced-form multivariate representations of macroeconomic variables. By imposing a minimum set of restrictions, it is possible to identify the structural shocks that drive the variables, such as exogenous innovations to the policy-controlled interest rate. Once the shocks are identified, the SVAR model allows one to study the dynamic responses of the variables to the shocks. There is considerable agreement in this literature that a decline in the policy rate leads to a hump-shaped temporary rise in economic activity, while prices increase persistently. These effects are typically used as a benchmark for the construction of monetary general equilibrium models of the business cycle (e.g., Christiano, Eichenbaum, and Evans 2005; Smets and Wouters 2007).

In contrast, little is known about the effectiveness and passthrough of monetary policy measures that expand the central bank balance sheets for a given policy rate 11 Indeed, this is exactly what the European Central Bank (ECB) and other major central banks have done in the aftermath of the financial crisis to counter the risks to macroeconomic and financial stability. The ECB, for instance, shifted from a variable-rate tender to a fixed-rate tender with full allotment; in addition, the pool of collateral accepted for refinancing operations has been enlarged and liquidity to banks has been provided at longer maturities than in the pre-crisis period. The ECB also conducted outright purchases of financial assets like covered bonds, asset-backed securities, and government bonds. A better understanding of the transmission mechanism and impact of such balance sheet policies on the macroeconomy is not only essential for policymakers, it is also important to construct theoretical monetary models for the analysis of unconventional monetary policy and the financial crisis.

In this study, we apply the SVAR methodology to analyze the macroeconomic effects and transmission mechanism of shocks to the ECB's balance sheet that are orthogonal to real economy

\footnotetext{
${ }^{1}$ The literature on the effects of so-called unconventional monetary policy, however, has been growing recently. Theoretical examples are Curdia and Woodford (2011) and Gertler and Karadi (2011). Empirical applications are Lenza, Pill, and Reichlin (2010), Peersman (2011), Ciccarelli, Maddaloni, and Peydro (2013), Fahr et al. (2013), and Gambacorta, Hofmann, and Peersman (2014).
} 
fluctuations, disturbances in financial markets, changes in the demand for central bank liquidity, and conventional innovations to the policy rate. We focus exclusively on the period between the onset of the financial crisis and the start of the Expanded Asset Purchase Program (EAPP) 2 More precisely, we first estimate a benchmark monthly SVAR model for the euro area containing output, consumer prices, the policy rate, central bank total assets, the CISS indicator of financial stress, and the spread between EONIA and the policy rate over the sample period 2007:M1-2014:M12. We find that an exogenous expansion in total assets leads to a significant but temporary rise in output and prices. The dynamic effects are very similar to the ones typically found in the literature on conventional interest rate innovations. This confirms that a central bank can also use its balance sheet to influence the real economy without altering the policy rate.

In a second step, we extend the VAR model and estimate the impact of balance sheet shocks on a set of financial market and banking-sector variables in order to shed more light on the transmission channels. We find that an exogenous rise in the ECB's balance sheet improves bank lending conditions for households and firms in the euro area, increasing the volume of bank lending significantly. Furthermore, the exchange rate depreciates, and there is a fall in money-market spreads as well as the intra-euro-area sovereign bond spreads vis-à-vis Germany. These results suggest that balance sheet policies of the ECB are also effective to counter risks to financial stability. On the other hand, we do not find a significant impact on (risk-free) German government bond yields.

To assess whether the consequences of the non-standard monetary policies have been economically meaningful, we then use the VAR model to conduct two counterfactual simulations. First, we simulate how the economy would have evolved without the oneyear long-term refinancing operations (LTROs) and the first Covered Bond Purchases Program (CBPP1), two measures that were launched in the summer of 2009. Second, a similar exercise is done

\footnotetext{
${ }^{2}$ Because the volume of asset purchases of the EAPP are anticipated a long time beforehand, and the EAPP can be considered as a monetary policy regime shift, we believe that the VAR model and identification strategy that we use are not appropriate to assess its effectiveness.
} 
for the three-year LTROs executed in December 2011 and March 2012. Both simulations reveal that the balance sheet policies sheltered the euro-area economy from worse counterfactual scenarios. For example, the recovery of economic activity and pickup of inflation in 2010 would have been much more sluggish without the two measures taken in 2009, while output and inflation would have been more than 1 percent lower in 2012 without the three-year LTROs.

Finally, we estimate the impact of the balance sheet shocks on output and prices in individual euro-area countries. The effects on prices are quite similar across countries. The output effects, however, are more diverse. In particular, we find a more subdued or insignificant impact in those countries that have been more affected by the financial crisis (e.g. Greece, Portugal, Cyprus, and Spain). The responses of output across countries turn out to correlate positively with the degree of capitalization of national banking sectors, which suggests that the solvency of the banking sector might be important for the effectiveness of the ECB's balance sheet policies.

This study is related to Gambacorta, Hofmann, and Peersman (2014), who estimate a panel VAR for eight industrialized countries and find favorable effects of central bank balance sheet shocks on output and inflation since the start of the crisis, but it differs in some important aspects. First, in the meantime we have several more years of data, which allows us to estimate a VAR model for a single currency. This implies that we do not have to pool data from different policy regimes and relatively diverse economic structures, which could distort the results. Second, our identification strategy of the shocks is much better tailored for the euro area. For example, Gambacorta, Hofmann, and Peersman (2014) do not distinguish between policy-induced and demand-driven innovations to the balance sheet of the central bank. While this is an appropriate approach for most industrialized countries, as discussed in the next sections, this could be misleading for the euro area given the fixed-rate tender with full allotment strategy of the ECB. A further isolation of policyinduced innovations is thus a relevant methodological extension of the present paper. Third, Gambacorta, Hofmann, and Peersman (2014) do not examine the transmission mechanism to bank lending and financial market variables, nor the differences across individual euro-area member countries, which are essential extensions to better understand the macro consequences. 
When we compare our findings with existing theoretical contributions on the effects of balance sheet policies, the area-wide results appear to be consistent with the models of Curdia and Woodford (2011) and Gertler and Karadi (2011). Specifically, Curdia and Woodford (2011) demonstrate that central bank credit policies (targeted purchases of private assets) can be effective in stimulating economic activity by lowering credit spreads when financial markets are sufficiently impaired. In a bank-based financial system, such as the euro area, an increase in the volume of liquidity provision to banks by the ECB can be considered as a way to expand credit to the private sector. The rise in the volume of bank lending to households and firms, and the decline of interest rate spreads that we find are thus in line with the predictions of their model. Cahn, Matheron, and Sahuc (2014) apply the model of Gertler and Karadi (2011) to the euro area and show that liquidity injections by the ECB into the banking sector could be effective in stimulating aggregate demand, because this alleviates balance sheet constraints of financial intermediaries, increasing bank lending. The area-wide results could indeed be interpreted as evidence in favor of the ability of the central bank to relax commercial banks' balance sheet constraints. On the other hand, the cross-country differences, with weaker effects in countries that were more hit by the crisis, are much harder to reconcile with these models. This is an issue that should be tackled in future research.

Some caution when interpreting the results is, however, required. In particular, the estimations represent the average impact of a generic series of exogenous balance sheet innovations during the crisis period. The shocks are thus a mixture of different policy actions affecting the ECB's balance sheet, the effects of which are not necessarily the same. This also applies to the counterfactuals, which are based on the average effects. The latter are also sensitive to the Lucas critique. More precisely, the counterfactuals implicitly assume that there are no changes in the deep structure of the economy without the interventions. Furthermore, since our sample period only covers the crisis period, the results do not necessarily imply that balance sheet policies are generally effective to influence the macroeconomy, i.e., also in non-crisis periods. Similarly, it is not clear whether the effectiveness and estimated magnitudes depend on the presence of a (zero) lower bound on risk-free rates. Nevertheless, the results could 
serve as a benchmark for further theoretical and empirical research on the transmission of balance sheet policies.

The remainder of the paper is organized as follows. In the next section, we provide an overview of the most important unconventional monetary policy measures of the ECB in the wake of the global financial crisis, and their influence on the central bank balance sheet. Section 3 presents the benchmark VAR model and the identification strategy to isolate exogenous balance sheet innovations. That section also relates the identification strategy to the theoretical literature on balance sheet policies. Section 4 reports the results of the benchmark estimations, whereas the impact on financial market and banking-sector variables is shown in section 5 . In section 6 , we report the counterfactual simulations, while the cross-country differences within the euro area are analyzed in section 7. Finally, section 8 concludes.

\section{The Balance Sheet of the ECB and the Financial Crisis}

The financial crisis has affected the balance sheet of the ECB in several waves. From the summer of 2007 onwards, euro-area banks suffered significant losses from the fallout of the subprime mortgage crisis in the United States. As a consequence, banks started to have doubts about their counterparties in the interbank market, which resulted in a shortage of liquidity and a collapse of activity in many financial market segments. In addition, several banks began to build up large liquidity buffers. To accommodate banks' increased (and unpredictable) demand for liquidity, the ECB started with several liquidity-providing operations in the second half of 2007. This continued until the collapse of Lehman Brothers, when the ECB decided to conduct a fixed interest rate with full allotment (FRFA) policy. In particular, from October 2008 onwards, banks had unlimited access to liquidity from the ECB at a pre-specified interest rate, as long as they could provide the required collateral. As can be seen in figure 1, this resulted in a first serious expansion of the ECB's balance sheet. At the same time, the ECB also decreased its key interest rates to very low levels.

Crucial for the analysis in this paper is that the FRFA policy has remained in place throughout the crisis for all standard 


\section{Figure 1. Balance Sheet of the ECB (Assets) in the Aftermath of the Financial Crisis}

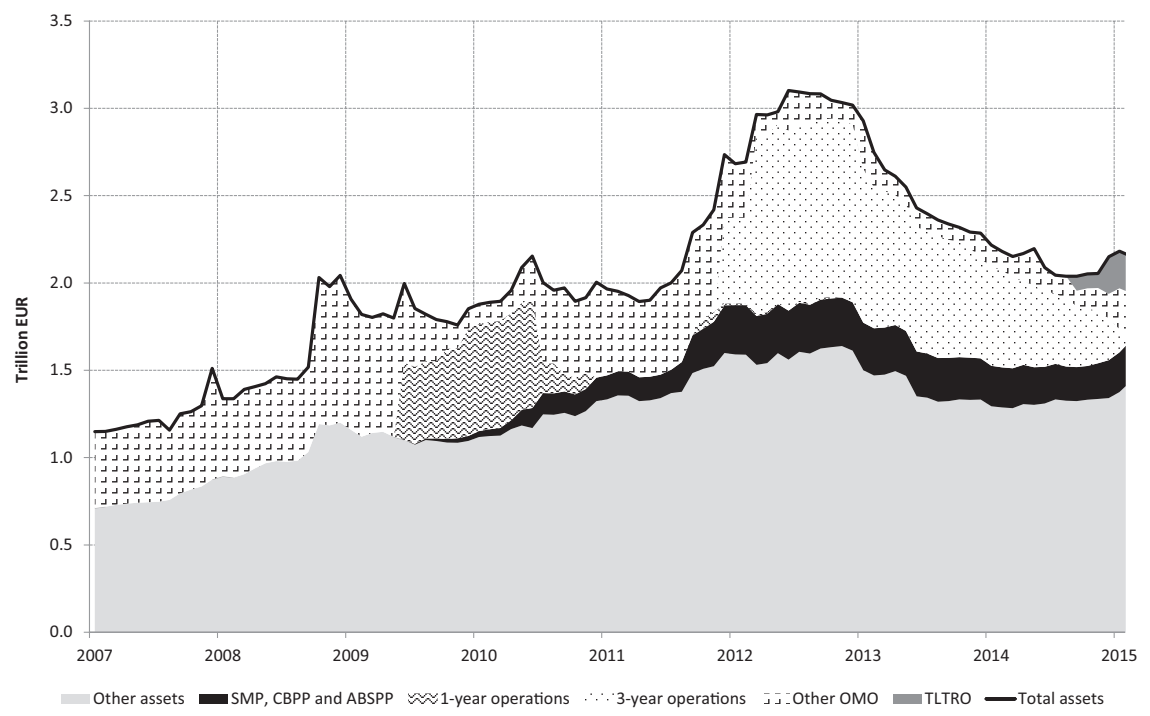

liquidity-providing operations of the ECB, although it was suspended temporarily for three-month operations in the spring of 2010. Specifically, the main challenge of this study lies in identifying changes in the balance sheet that could be interpreted as exogenous monetary policy decisions, i.e., not the result of movements in other variables. The FRFA policy, however, implies that fluctuations in the volume of liquidity distributed by the ECB to the banking sector between October 2008 and the launch of the Expanded Asset Purchase Program in early 2015 were essentially demand driven. Nevertheless, shifts in the volume of lending to the banking sector that are the consequence of deliberate monetary policy decisions were still possible and did happen during that period. In particular, the ECB has conducted a number of non-standard monetary policy measures that raised the demand for liquidity by banks and hence the size of its balance sheet, such as alterations to the collateral requirements for its liquidity-providing operations. The list of eligible collateral accepted in the refinancing operations has been extended several times, e.g., in October 2008 and December 2011, 
allowing banks to refinance less liquid assets, expanding the balance sheet of the ECB. On the other hand, the collateral framework has also been made more restrictive at some points in time, e.g., by limiting the range of eligible assets or by changing haircuts 3

The ECB has also stimulated liquidity demand from the banking sector by extending the maximum maturity of its longer-term refinancing operations (LTROs). Whereas in the pre-crisis period the ECB only offered operations with a maturity up to three months, the maximum maturity was extended to six months in February 2009, then to twelve months in June 2009. There have also been two very important refinancing operations with a maturity of thirty-six months in December 2011 and March 2012 (and an option to repay the funds after one year) and a series of so-called targeted LTROs with a (maximum) maturity of forty-eight months from the summer of 2014 onwards. The latter provide funding for banks that expand their lending to the private sector. As shown in figure 1, all these operations got considerable interest by banks, boosting the balance sheet of the ECB. Furthermore, in order to alleviate banks' funding problems in foreign currency, the ECB has offered funding in foreign currency, such as U.S. dollars and Swiss francs, in cooperation with other central banks. These operations have at times been suspended and reintroduced, resulting in balance sheet fluctuations that are at least partly the consequence of policy decisions.

The ECB has further conducted several outright asset purchase programs during the sample period, which influenced the size of its balance sheet (see figure 1). Specifically, the ECB conducted two Covered Bond Purchase Programs (CBPPs) between June 2009 and October 2012, which implied outright purchases of €76.4 billion in covered bonds issued by banks in the euro area. Between May 2010 and the summer of 2012, the ECB also intervened several times in the secondary markets of some euro-area government bonds in the context of its Securities Markets Program (SMP). Overall, the ECB bought $€ 219.5$ billion of government bonds in the context of the SMP. In addition, a third CBPP has been launched since October 2014, as well as an asset-backed securities purchase program (ABSPP) since November 2014.

\footnotetext{
${ }^{3}$ In early 2009, for instance, the ECB raised its rating threshold for ABSs from one $A$ rating to two AAA ratings at issuance.
} 
In sum, there have been several deliberate monetary policy decisions after the introduction of the FRFA policy (which was in fact also a policy decision) that had an influence on the balance sheet of the ECB. Hence, it should be possible to isolate exogenous policyinduced balance sheet shocks. The identification strategy to do so will be discussed in the next section. Notice that we explicitly end our sample period in December 2014. More specifically, in January 2015, the Governing Council of the ECB announced an Expanded Asset Purchase Program (EAPP - mainly public debt securities) of $€ 60$ billion per month until at least September 2016. Since the monthly volumes of the purchases are announced several months in advance, these shifts in the balance sheet of the ECB after January 2015 can therefore no longer be considered unanticipated shocks.

\section{Euro-Area SVAR Model for the Financial Crisis}

\subsection{Benchmark Specification}

Structural VAR models are typically used to estimate the macroeconomic effects of conventional monetary policy innovations, e.g., Christiano, Eichenbaum, and Evans (1999) for the United States and Peersman and Smets (2003) for the euro area. SVARs impose very little theoretical structure on the data and can be used to establish some relevant stylized facts. In this paper, we also use the SVAR methodology to explore the dynamic effects of unconventional monetary policies. The benchmark VAR model that we consider has the following representation:

$$
Y_{t}=\alpha+A(L) Y_{t-1}+B \varepsilon_{t},
$$

where $Y_{t}$ is a vector of endogenous variables, $\alpha$ a vector of constants, $A(L)$ a matrix polynomial in the lag operator $L$, and $B$ the contemporaneous impact matrix of the mutually uncorrelated disturbances $\varepsilon$.

In the benchmark specification, the vector of endogenous variables $Y_{t}$ contains six euro-area variables: the log of seasonally adjusted real GDP, the log of seasonally adjusted consumer prices, the log of central bank total assets, the level of financial stress as measured by the Composite Indicator of Systemic Stress (CISS), the spread between EONIA and the main refinancing operations (MRO) 
rate, and the MRO policy rate. The VARs in this study are estimated in (log) levels over the sample period 2007:M1-2014:M12.4

Several remarks about the VAR model and selection of variables are worth mentioning. First, a number of empirical studies on unconventional monetary policy use data starting before the financial crisis (e.g., Lenza, Pill, and Reichlin 2010; Peersman 2011; Giannone et al. 2012). However, this may not be adequate to assess the effects of the policy measures that were taken in the aftermath of the financial crisis. Specifically, banks and sovereign bond markets in the euro area behaved very differently in the financial crisis compared to the pre-crisis period. Moreover, before the summer of 2007, the ECB never explicitly used its balance sheet as a policy tool to influence macroeconomic and financial market conditions.5 This is why our sample period starts in 2007. Conversely, this implies that our results are only representative for a period of severe financial stress, where also the policy rate reached its (zero) lower bound. It is thus not clear whether our results are also valid for balance sheet policies in normal times and high(er) interest rate regimes. Curdia and Woodford (2011), for example, show that balance sheet policies might only be effective when financial markets are sufficiently disrupted.

Second, the benchmark specification should capture the main macroeconomic, financial, and monetary interactions during the financial crisis. Output and prices represent the macroeconomic developments in the sample period, while the MRO rate captures conventional monetary policy. The central bank balance sheet variable that we use in the estimations is ECB total assets, whose dynamics most closely resemble the balance sheet measures discussed in section 2, i.e., additional lending to banks and securities held for monetary policy purposes. Notice that Curdia and Woodford

\footnotetext{
${ }^{4}$ Estimation in (log) levels allows for implicit cointegration relationships in the data (Sims, Stock, and Watson 1990). Given the short sample available, we do not perform an explicit analysis of the long-run behavior of the economy. For real GDP, we construct a monthly measure using the Chow-Lin interpolation procedure and monthly industrial production as a reference series.

${ }^{5}$ One notable example of a change in the size of the balance sheet that was not related to the monetary policy stance of the ECB is the drop in the balance sheet prior to the changeover of national banknotes into euro banknotes in January 2002 .
} 
(2011) argue that only targeted purchases of private assets (credit policy) can stimulate the economy, while purchases of (riskless) treasury bonds are not effective in stimulating aggregate demand. This might suggest that it is mainly the composition of the balance sheet, rather than total assets, that matters for the effectiveness of balance sheet policies. However, the ECB did not implement its policy via purchases of risk-free treasury bonds before 2015. The bulk of the interventions were refinancing operations with commercial banks. Accordingly, changes in the size of the balance sheet are sufficient to capture the exposure of the ECB to the private sector. Specifically, in a financial system that is mainly bank based, such as the euro area, an increase in the exposure of the central bank to the banking system is the most straightforward way of expanding the volume of credit to the private sector. This is also the case for the SMP government bond purchases by the ECB. The rise in the ECB's total assets related to these purchases was arguably not a simple exchange of risk-free government debt for risk-free central bank reserves, since these bonds were issued by euro-area countries under severe financial stress. The purchases in the context of SMP can instead be considered a form of credit policy, in particular given the fact that these bonds were impairing the credit intermediation capacity of commercial banks.

As an alternative for total assets of the ECB, we could use liabilities-based measures such as the monetary base. However, decisions related to, for instance, the SMP would then not be included. The purchases under this program have been sterilized during our sample, and therefore do not affect the monetary base. Nevertheless, the results prove to be robust when we use the monetary base as the balance sheet indicator 6

Third, we include the CISS indicator of Holló, Kremer, and Lo Duca (2012) in the benchmark VAR model in order to capture financial stress and economic risk during the sample period. The CISS indicator summarizes information on financial stress in euro-area money markets, bond markets, equity markets, foreign exchange markets, and financial intermediaries. Conditioning on such an indicator is also crucial to disentangle exogenous changes in the central

\footnotetext{
${ }^{6}$ These results are available upon request.
} 
bank balance sheet from endogenous responses to financial stress and uncertainty. Specifically, as discussed in section 2, innovations to the balance sheet could be demand induced due to the FRFA policy, whereas several unconventional monetary policy measures of the ECB were taken in direct reaction to financial and macroeconomic jitters. Failing to take into account the endogenous response of the balance sheet to financial turbulence and economic uncertainty could seriously bias the estimation results (Gambacorta, Hofmann, and Peersman 2014). Indeed, figure 2 shows that the year-on-year percentage change in total ECB assets is closely related to the CISS indicator. The positive co-movement between both variables mainly reflects the endogenous response of the balance sheet to financial stress 7 Finally, the benchmark VAR includes the spread between EONIA and the MRO rate, which will also be useful for the identification of exogenous balance sheet shocks.

\subsection{Identification of Balance Sheet Shocks}

Isolating exogenous balance sheet shocks involves making identifying assumptions. As explained in section 2, fluctuations in the ECB's balance sheet are a combination of changes in monetary policy that could be interpreted as exogenous and an endogenous response to developments in the economy. The latter reflects, in turn, the systematic reaction of monetary policy to financial stress and macroeconomic fluctuations, as well as the demand-driven nature of the FRFA policy 8 To identify exogenous innovations to the balance sheet, we use a mixture of zero and sign restrictions on the contemporaneous matrix $B$ in equation (1), which can be found in table 1 .

\footnotetext{
${ }^{7}$ The positive correlation between the size of the balance sheet and our indicator of financial stress is analogous to the positive correlation between interest rates and inflation in conventional monetary policy VARs. Also in that case, the positive (unconditional) correlation is mainly the result of an endogenous response of monetary policy to changes in prices, rather than exogenous monetary policy shocks which drive interest rates and prices in opposite directions.

${ }^{8}$ The benchmark estimations reveal that only 25 percent of the forecast error variance decomposition of total ECB assets at horizon 0 is driven by unconventional balance sheet shocks, which even declines to 6 percent at longer horizons. Fluctuations in the ECB's balance sheet are thus mainly endogenously driven by other shocks in the economy, which underscores the importance of isolating exogenous innovations.
} 
Figure 2. ECB Balance Sheet and Financial Stress in the Euro Area

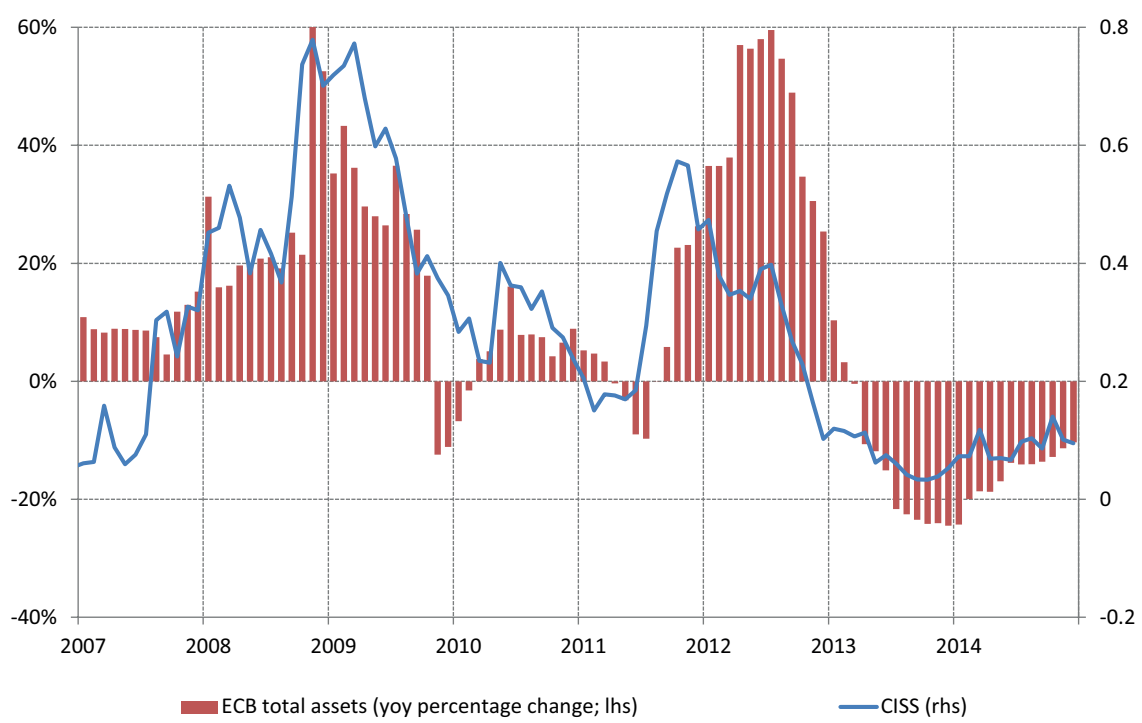

Table 1. Identification of an (Unconventional) Central Bank Balance Sheet Shock

\begin{tabular}{|c|c|c|c|c|c|}
\hline Output & Prices & $\begin{array}{c}\text { CB Total } \\
\text { Assets }\end{array}$ & CISS & $\begin{array}{c}\text { EONIA-MRO } \\
\text { Spread }\end{array}$ & $\begin{array}{c}\text { Policy } \\
\text { Rate }\end{array}$ \\
\hline 0 & 0 & $\geq 0$ & $\leq 0$ & $\leq 0$ & 0 \\
\hline
\end{tabular}

First, we assume that there is only a lagged impact of a balance sheet shock on output and consumer prices, i.e., the contemporaneous impact on both variables is restricted to be zero. Conversely, innovations to output and prices are allowed to have an immediate effect on the balance sheet of the central bank. This assumption, which is also made in most VAR studies on the effects of conventional monetary policy shocks (e.g., Bernanke and Blinder 1992; Christiano, Eichenbaum, and Evans 1999; Peersman and Smets 2003), is plausible for monthly estimations, and allows us to disentangle monetary policy shocks from real economy disturbances such as aggregate supply and demand shocks. 
Second, we assume that an unconventional monetary policy shock that increases the balance sheet of the ECB does not increase financial stress. This restriction, which embodies the notion that exogenous innovations to the balance sheet have a mitigating effect on financial stress, is required to disentangle such innovations from the endogenous response of the balance sheet to financial stress. See Gambacorta, Hofmann, and Peersman (2014) for a similar reasoning. 9 In particular, it follows as a complementary restriction from the assumption that central bank assets typically increase in response to a rise in the CISS indicator. The latter reflects the idea that (i) the ECB reacts to increased financial stress by expanding its balance sheet, and (ii) due to the FRFA policy, the balance sheet of the ECB rises endogenously when financial market uncertainty increases.

Third, we assume that an expansionary balance sheet shock does not increase the EONIA-MRO spread. Also this restriction is motivated by the FRFA policy and the accompanying unlimited access of banks to central bank liquidity. Specifically, there could have been (exogenous) shocks to the demand for bank reserves without a policy action from the ECB, which have lowered the CISS indicator and augmented the size of the central bank balance sheet during the sample period. A rise in the demand for bank reserves, however, typically raises EONIA, and hence also the EONIA-MRO spread for a given policy rate. In contrast, an expansionary balance sheet shock that is the consequence of an unconventional monetary policy action typically increases the liquidity surplus, exerting downward pressure on EONIA and the spread with the policy rate 10 This restriction is an extension to the identification strategy of Gambacorta, Hofmann, and Peersman (2014), who do not disentangle demanddriven from policy-induced balance sheet innovations for a panel of

\footnotetext{
${ }^{9}$ Instead of the CISS indicator, Gambacorta, Hofmann, and Peersman (2014) use the VIX indicator, which only captures stock market volatility. Notice that this restriction implies that expansions in the balance sheet which did lead to increased financial markets volatility are not identified and hence captured by the other innovations in the VAR.

${ }^{10}$ Notice that not all unconventional monetary policy measures imply downward pressure on EONIA. The impact of the SMP on liquidity, for instance, has been sterilized. Moreover, EONIA can never fall below the interest rate on the deposit facility of the ECB. To account for this, the sign restriction is implemented in a weak form.
} 
eight industrialized countries. However, given the FRFA of the ECB, such a distinction is important for the euro area.

Finally, given that we want to estimate the dynamic effects of innovations to the ECB's balance sheet that are orthogonal to shifts in the policy rate, the identified shocks have a zero contemporaneous impact on the MRO rate.

All sign restrictions are imposed on impact and the first month after the shock, and implemented in a weak form, i.e., as smaller/larger than or equal to zero. This allows for the possibility that an unconventional monetary policy measure, for example, influences the CISS indicator immediately but influences central bank assets only with a lag. Hence, it accommodates for the fact that some monetary policy decisions are announced before they are implemented.

\section{Benchmark Estimation Results}

The VAR is estimated over the sample period 2007:M1-2014:M12. Data were taken from the ECB Statistical Data Warehouse and Datastream. Based on the usual lag-length selection criteria, the estimations include three lags of the endogenous variables. Most criteria even suggest a shorter lag length, but the results proved robust to different specifications of the lag length. We use a Bayesian approach for estimation and inference. The prior and posterior distributions of the reduced-form VAR belong to the Normal-Wishart family. To draw the "candidate truths" from the posterior, we take a joint draw from the posteriors of the reduced-form VAR parameters, as well as a random possible decomposition $B$ of the variance-covariance matrix. If the draw of the VAR system is stationary and satisfies the restrictions, the draw is kept. Otherwise, the draw is rejected by giving it a zero prior weight. For details of the estimation procedure and implementation of restrictions, we refer to Peersman (2005) or Uhlig (2005). Ten thousand successful draws from the posterior are used to produce the figures 11

\footnotetext{
${ }^{11}$ The results are robust when we use the approach of Arias, Rubio-Ramirez, and Waggoner (2014) for the implementation of the restrictions. See also Benati (2014) for a discussion of the robustness of our results.
} 
Figure 3. Time Series of Cumulative Identified Balance Sheet Shocks

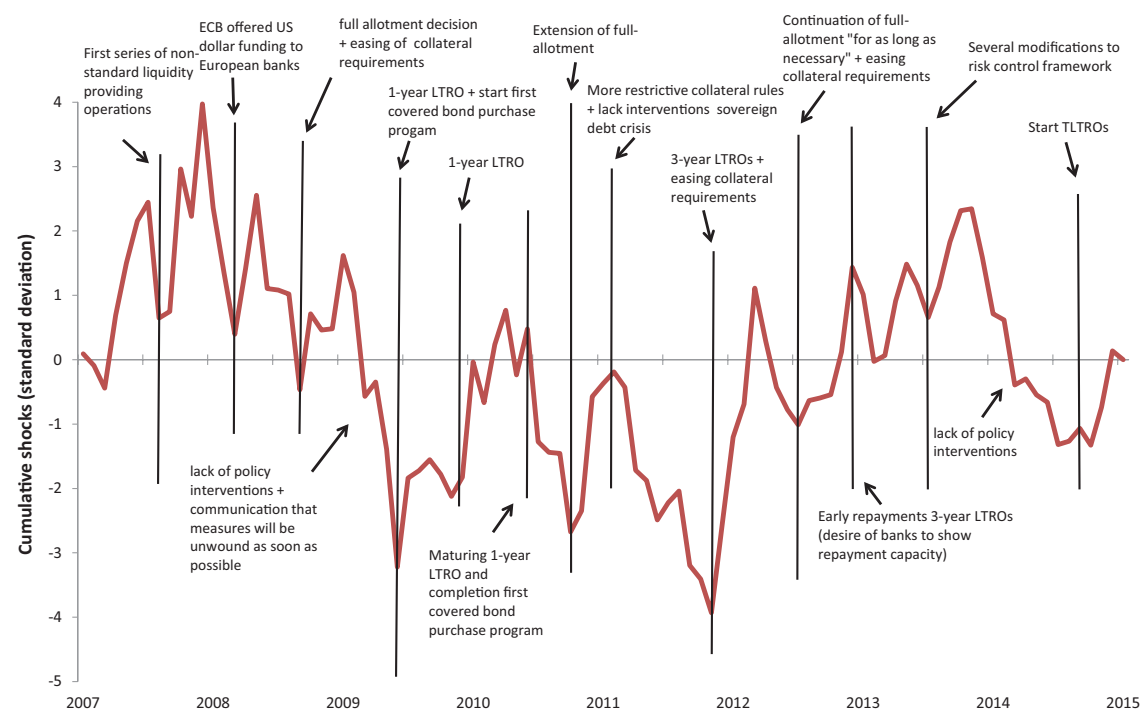

\subsection{Time Series of Exogenous Balance Sheet Innovations}

Before we discuss the dynamic effects and transmission mechanism of the balance sheet shocks, we first examine the time series of the identified shocks. An inspection of the time series of the shocks should help to interpret their exact source more carefully, and assess whether the major measures taken by the ECB in the aftermath of the crisis are captured by the estimated innovations. Figure 3 shows the median cumulative time series of the balance sheet shocks. The scale is measured in standard deviations of the innovations. By construction, the sum of the shocks is zero over the whole sample period. A rise in the cumulative shock series implies an expansionary balance sheet shock, while a decline reflects a tightening of the balance sheet relative to the average endogenous response to the other shocks hitting the economy.

The figure reveals that the identified shocks capture the dates of important unconventional monetary policy measures. As most decisions have to some extent an unexpected component, this indicates that our identification strategy is plausible. Examples of (series 
of) expansionary balance sheet shocks identified by the VAR model are the first series of non-standard liquidity providing operations in the summer of 2007, the decision of the Governing Council to offer U.S. dollar funding to Eurosystem counterparties in March 2008, the FRFA policy and the easing of collateral requirements in October 2008, the CBPP and one-year LTROs in 2009, the three-year LTROs of December 2011 and March 2012, the easing of collateral requirements and the announcement that the FRFA will be continued "for as long as necessary and at least another six months" in June 2012, several modifications to the risk control framework in July 2013, and the targeted LTROs (TLTROs) launched at the end of the sample period. Somewhat surprising, the start of the SMP in May 2010 and the second phase of considerable government bond purchases under this program in the summer of 2011 are not identified as expansionary balance sheet shocks, which implies that the corresponding rise in the ECB's balance sheet can mainly be considered an endogenous reaction to the ongoing macroeconomic and financial jitters 12

The periods that are identified as restrictive balance sheet shocks are typically associated with a lack of policy measures, despite a worsening of economic conditions and financial stability. Examples are the banking crisis in 2009 and the sovereign debt crisis in 2011. Also, the end of the one-year LTROs and completion of the first CBPP in June 2010 are identified as a tightening of the (unconventional) monetary policy stance. Interestingly, the early repayments of three-year LTROs in January 2013 resulted in a negative shock to the balance sheet of more than one standard deviation. Such negative shock could be related to a desire by counterparties to avoid stigma attached to using the LTROs by signaling improvements in their funding conditions (ECB 2013a). In sum, we can conclude that the identified balance sheet shocks make sense, and capture the most important non-standard monetary policy measures of the ECB during the sample period.

\footnotetext{
${ }^{12}$ Notice that the August 2012 announcement of the Outright Monetary Transactions (OMT) program is not identified as a balance sheet shock either, which can be explained by the fact that this program has not involved any actual purchases during our sample period. Potential effects are thus captured by the other innovations in the VAR system.
} 


\subsection{Impulse Response Analysis}

Figure 4 shows the impulse responses to a one-standard-deviation balance sheet innovation. The dotted lines are the median impulse responses of the posterior distributions, while the shaded areas represent the 68 percent posterior probability regions of the estimated responses. The shock is characterized by an increase in total ECB assets between 1.0 and 2.5 percent, which fades out after about six months. While being (weakly) imposed by the sign restriction on impact and the first month after the shock, an expansionary balance sheet shock leads to a significant decline of the CISS indicator that lasts for more than one year. Also, the spread between EONIA and the MRO rate is assumed to fall on impact, but remains negative for about five months.

The dynamics of real GDP and consumer prices reveal that the unconventional balance sheet policies conducted by the ECB in the aftermath of the financial crisis were effective in supporting the macroeconomy. Both variables display a significant increase after an expansion in the central bank balance sheet. Real GDP is found to rise with a peak effect after about nine months of approximately 0.1 percentage points, and to gradually return after eighteen months to the value it would have taken without the balance sheet shock. Compared to the existing evidence on the transmission of conventional monetary policy shocks that are associated with a change in the short-term interest rate, the response pattern of output turns out to be qualitatively very similar. The impact on consumer prices is, however, somewhat different. Specifically, as can be seen in figure 4 , the pattern of consumer prices coincides more or less with that of the output response following a balance sheet shock, while the impact of interest rate shocks on the price level is typically found to be very sluggish, with a peak only after about two years or more.

Finally, we observe a tightening of the policy rate after a couple of months, which reflects the average conventional monetary policy reaction function during the sample period, i.e., the stabilization of output and inflation fluctuations by the ECB. This is not a surprise, given that the policy rate did fluctuate during the sample period and only reached its (zero) lower bound at the end of the sample period (from 15 to 5 basis points in September 2014). 


\section{Figure 4. Impulse Responses to Balance Sheet Shocks in the Euro Area}
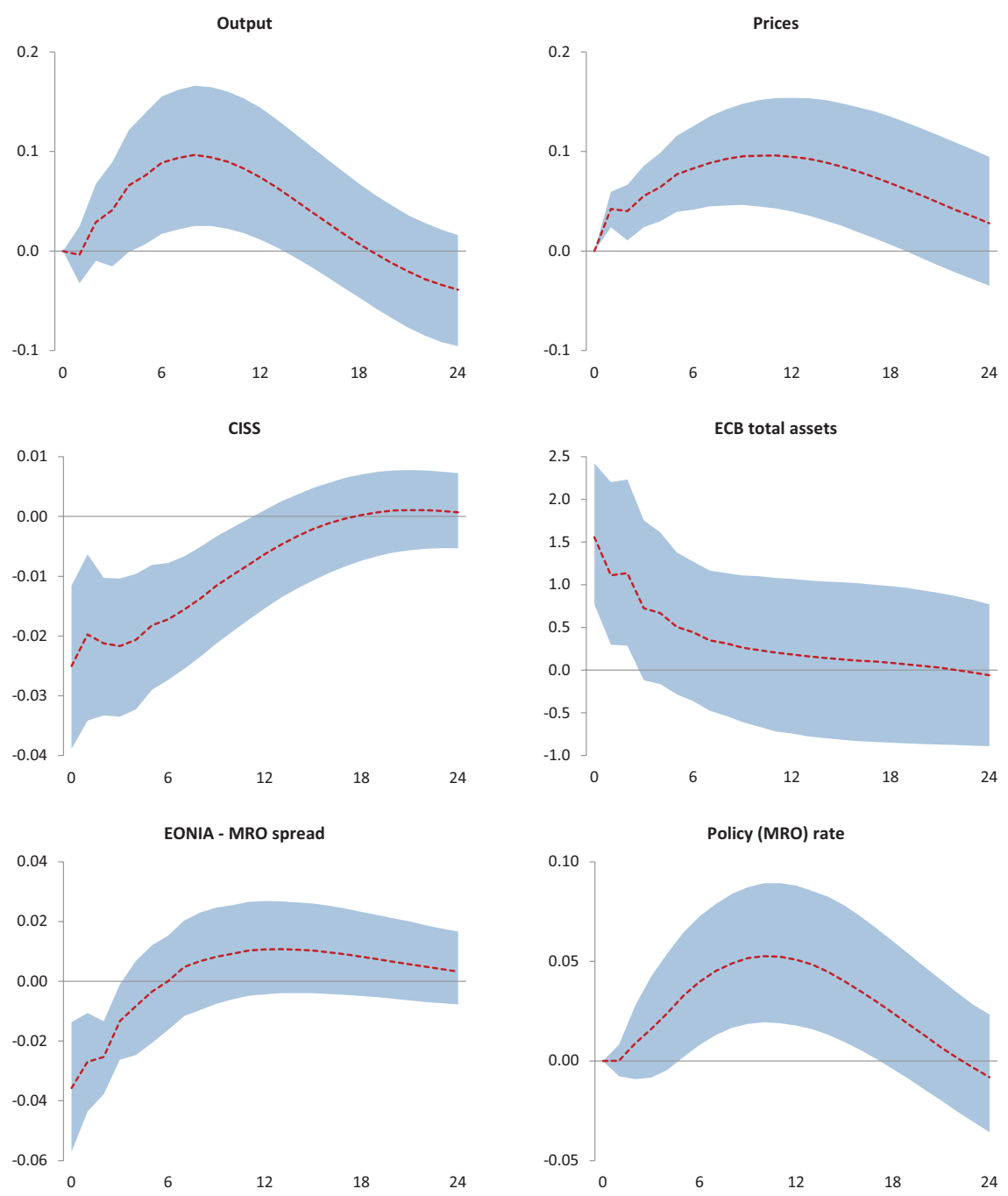

Note: Figures show median responses, together with 16th and 84th percentiles of the posterior distribution; horizon is monthly. 
Accordingly, we should consider the magnitudes of the estimated output and inflationary effects as a lower bound of the effectiveness of balance sheet shocks. More precisely, the macroeconomic effects should in principle be larger when the policy rate does not react to the stimulative effects of the liquidity injections, a premise that has theoretically also been shown by Cahn, Matheron, and Sahuc (2014).

\section{Transmission Channels}

In this section, we analyze the transmission channels of the central bank balance sheet shocks to the real economy in more detail. Given that borrowing and lending in the euro area predominantly take place through the intermediation of the banking system, and most ECB unconventional monetary policy actions were primarily aimed at influencing the banking sector, we first examine the impact of the shocks on a set of bank lending variables. In a next step, we assess whether the balance sheet policies also had an impact on a number of financial market variables that are not included in the benchmark model. We do this by extending the basic SVAR model as follows:

$$
\begin{aligned}
{\left[\begin{array}{c}
Y_{t} \\
Z_{t}
\end{array}\right]=} & {\left[\begin{array}{l}
\alpha \\
\gamma
\end{array}\right]+\left[\begin{array}{cc}
A(L) & 0 \\
C(L) & D(L)
\end{array}\right]\left[\begin{array}{l}
Y_{t-1} \\
Z_{t-1}
\end{array}\right] } \\
& +\left[\begin{array}{cc}
B & 0 \\
E & F
\end{array}\right]\left[\begin{array}{c}
\varepsilon_{t} \\
v_{t}
\end{array}\right]
\end{aligned}
$$

We use a block-diagonal structure to estimate the effects of a balance sheet shock on the banking and financial market variables, i.e., we estimate a so-called near-VAR. As before, $Y_{t}$ is a vector of the benchmark endogenous variables, and $B$ the contemporaneous impact matrix of the shocks $\varepsilon_{t}$. $Z_{t}$ is a vector containing the banking or financial variables of interest. Each time, we include two (related) variables in $Z_{t}$-for instance, the volume of bank lending to households and the corresponding lending rate. The variables are paired along the rows of the figures, i.e., the two variables of a single row in the figures are each time included as a pair in the near-VAR. We should point out, however, that the choice of pairing does not influence the estimates. In order to keep the balance sheet shock and the 
dynamics of the benchmark variables invariant to the inclusion of the additional variables, we assume that the banking and financial market variables do not affect the block of the benchmark endogenous variables. This approach is very similar to that of Peersman and Smets (2003), who estimate the impact of a conventional monetary policy shock on various euro-area macroeconomic variables. The CISS indicator-reflecting stress in the banking system and a wide range of asset markets - should be a sufficient proxy to capture the state of financial and banking markets 13

The procedure to estimate the near-VARs is very similar to the benchmark model of the previous section. The only difference is that near-VARs require Gibbs sampling to draw the "candidate truths" from the posterior. We discard the first 5,000 draws as "burn-in" and then use 10,000 successful draws from the posterior to produce the figures. We assess for convergence of the ergodic distribution by computing the draws' inefficiency factors, which are the inverse of Geweke's spectral-based measure of relative numerical efficiency of the draws. The inefficiency factors are always far below the value of 20 , typically even below 0.005 , providing evidence of convergence to the ergodic distribution.

\subsection{Bank Lending}

The dynamic effects of a balance sheet shock on a set of euro-area bank lending variables are shown in figure 5 . The results suggest that the unconventional monetary policy measures of the ECB did support bank lending to households and firms during the financial crisis. In particular, the volume of lending both to non-financial corporations and to households rises significantly following an expansion in the central bank balance sheet for a given policy rate. The peak of the response of loans to non-financial corporations is later than the peak of loans to households. This is in line with existing evidence, which typically finds that loans to households move contemporaneously with output, whereas loans to non-financial corporations tend to lag output (ECB 2013b). These findings are also consistent

\footnotetext{
${ }^{13}$ As a robustness check, we have also estimated VARs where the additional variables are included in the block of benchmark endogenous variables. The results are very similar.
} 


\section{Figure 5. Impact of Balance Sheet Shocks on Bank Lending in the Euro Area}
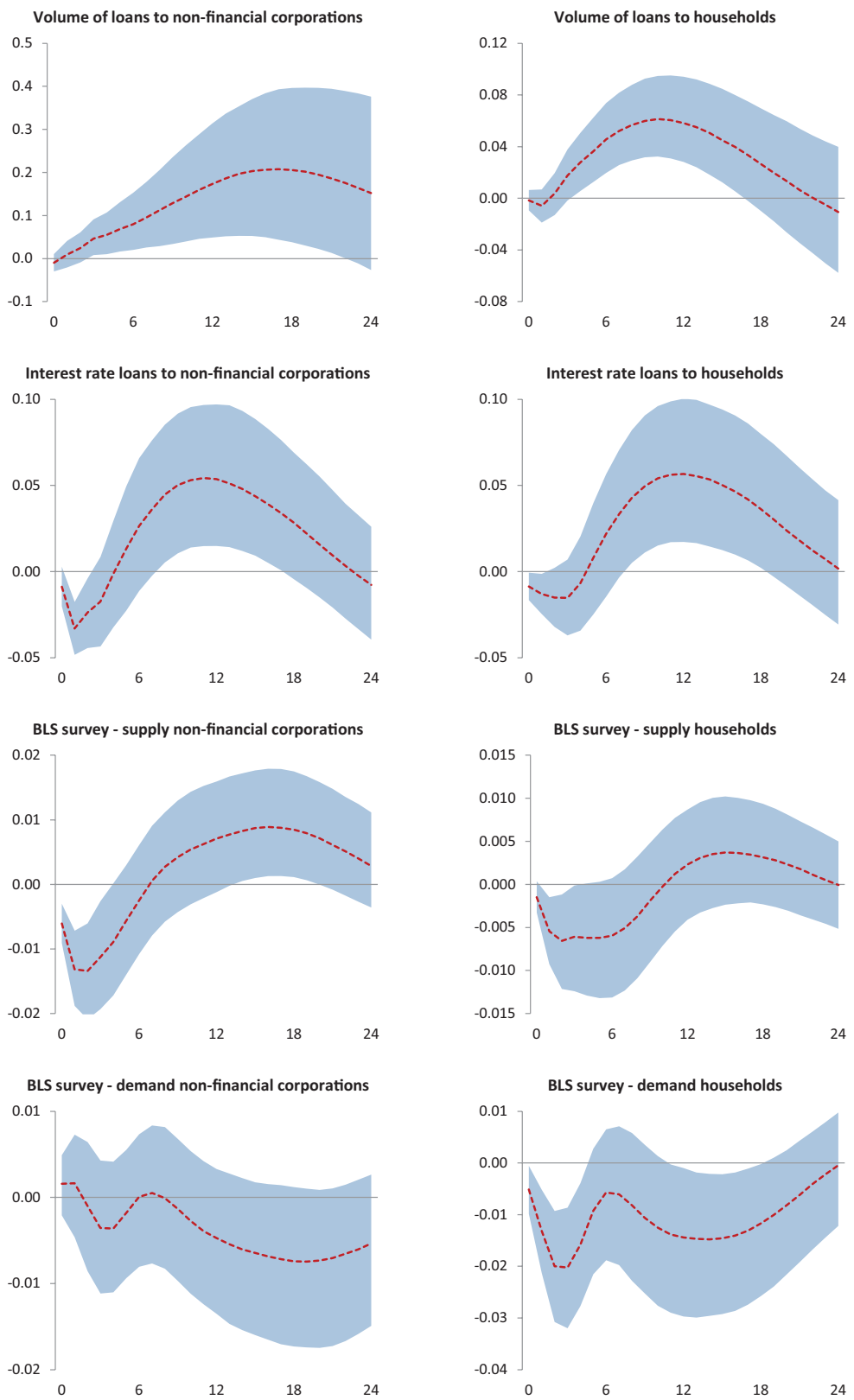

Note: Figures show median responses, together with 16th and 84th percentiles of the posterior distribution; horizon is monthly. 
with those of Affinito (2013), who finds that lending reacts positively to changes in unconventional monetary policy using micro firm data.

The impulse responses of the interest rates charged on loans to households and firms denote that the rise in the volume of lending is essentially supply driven. In particular, while the volume of lending increases, there is a decline of both lending rates in the short run after an expansionary balance sheet shock. The increase in bank lending rates after six months is in line with the endogenous reaction of the policy rate documented before. The impact on bank lending is consistent with the existence of a bank lending channel of balance sheet policies. This is further supported by the regular Bank Lending Survey (BLS) conducted by the ECB on supply and demand conditions of bank loans 14 The question on supply conditions asks how the bank has changed its credit standards for loans or credit lines to, respectively, households and firms. The question on demand conditions asks how the demand for loans and credit lines by households and firms has changed, apart from normal seasonal fluctuations. The bottom part of figure 5 shows the impulse responses of both indices to the identified shocks. A decline in the supply index implies a loosening of credit standards, whereas a fall in the demand index corresponds to a decline in loan demand. The impulse responses reveal that supply conditions are significantly loosened after a shock to the balance sheet, in contrast to demand conditions. The response of demand conditions for households is even negative in the short run. In sum, the responses of the BLS data confirm that it is the supply of bank loans and not the demand that increases after an expansion in the ECB's balance sheet, which corroborates the existence of a bank lending channel of monetary policy in the spirit of Bernanke and Blinder (1988) and Kashyap and Stein (1995). It is also compatible with recent models for unconventional monetary policy, such as Curdia and Woodford (2011) or Gertler and Karadi (2011).

\footnotetext{
${ }^{14} \mathrm{As}$ the BLS is a quarterly survey, the series is linearly interpolated to obtain a monthly series. For more details about the construction of the series, see http://www.ecb.europa.eu/stats/money/surveys/lend/html/index.en.html.
} 


\subsection{Financial Markets}

The impact of a balance sheet shock on a number of financial market variables is shown in figure 615 Consistent with the rise in the volume of bank loans, there is a significant rise of M3 in the medium term after an expansionary innovation to the ECB's balance sheet. Furthermore, there is a fall in the three-month EURIBOR rate, which can be explained by the drop in EONIA, as well as by a decline in the credit risk premium embedded in EURIBOR. There is indeed a fall in the EURIBOR-OIS spread, which reflects the favorable impact of the balance sheet measures on the risk premium for banks in the interbank market. In line with this, credit default swaps (CDSs) for banks drop between 4 and 10 basis points. The liquidity support of the ECB hence also lowers the probability investors attach to a credit event in the banking sector.

Figure 6 further shows that equity prices increase after a balance sheet shock, although the error bands are very wide. There is also a depreciation of the nominal effective exchange rate of approximately 0.4 percent. The latter is consistent with an exchange rate channel of the balance sheet policies. Furthermore, we find that a balance sheet shock has no significant impact on (risk-free) German government bond yields. In contrast, there is a significant decline of the sovereign yield spreads vis-à-vis Germany. The latter finding is in line with common perception and evidence (e.g., Acharya and Steffen 2015) that in response to the ample ECB liquidity, many banks have bought government bonds of euro-area countries under financial stress, and that this has lowered the spread between the yields of these countries and the German bund. Overall, the rise in the volume of bank lending to households and firms documented above, the decline of interest rate spreads, and the absence of an impact on the risk-free (German) rate are compatible with the models of Curdia and Woodford (2011) and Gertler and Karadi (2011).

${ }^{15} \mathrm{~A}$ caveat of the results shown in figure 6 is that our identification scheme weakly imposes a decline in the composite overall measure of financial stress (CISS) on impact. Nevertheless, it is useful to investigate whether beneficial effects are observed in a wide range of financial market segments, including its persistence. 


\section{Figure 6. Impact of Balance Sheet Shocks on Financial Market Variables in the Euro Area}
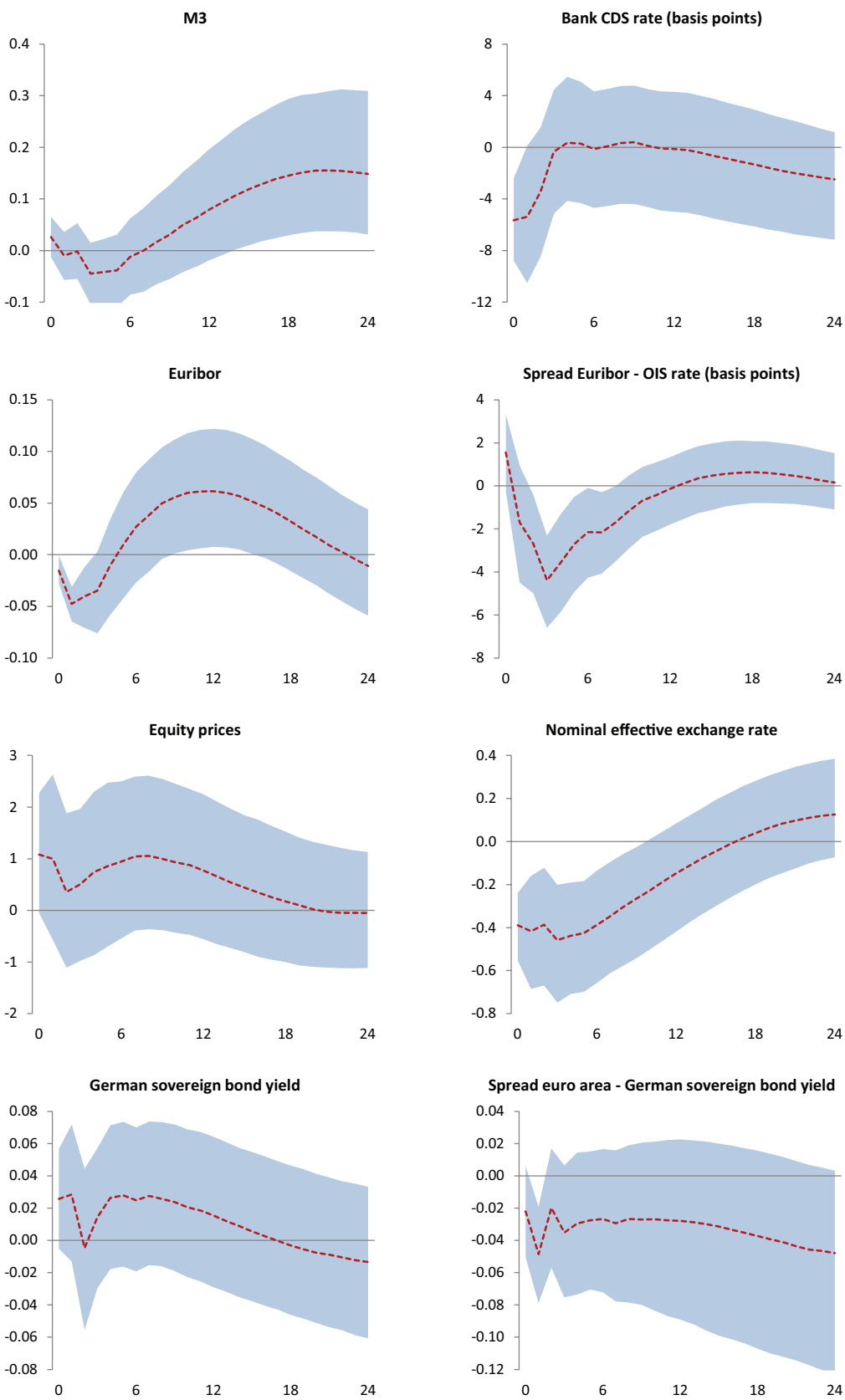

Note: Figures show median responses, together with 16th and 84th percentiles of the posterior distribution; horizon is monthly. 


\section{The Economic Relevance of the Balance Sheet Policies}

In the previous section, we have documented that the ECB can successfully stimulate economic activity and raise inflation by expanding its balance sheet. Yet, it is not clear whether the consequences have been economically meaningful. To examine the economic relevance in more detail, we conduct two counterfactual simulations 16 In the first, we measure how the macroeconomy would have evolved without the one-year LTROs and the first CBPP launched in the summer of 2009. In the second, we do the same exercise for the threeyear LTROs implemented in December 2011 and March 2012. These were two major policy decisions that clearly expanded the balance sheet of the ECB. For both counterfactuals, we use the near-VAR model with the (total) volume of bank lending and the bank lending rate as $Z_{t}$ variables.

Counterfactuals require assumptions, which implies that the results need to be taken with more than the usual degree of caution. In particular, we implicitly assume that there are no changes in the underlying economic structure (parameters of the VAR model) in the counterfactual scenarios. This implies that the counterfactuals, like any counterfactual based on VAR models, are sensitive to the Lucas critique. For the CBPP, we shock the balance sheet of the ECB (negatively) by €61 billion between July 2009 and June 2010 as the counterfactual scenario. This corresponds to the actual purchases of the ECB during that period. For the one-year LTROs, we shock the balance by $€ 198$ billion in June 2009, and by €82 billion in December 2009. This is the net increase of the ECB's total assets in these months 17 Notice that the actual (gross) volume of lending in the context of the one-year LTROs was, respectively, €442 and $€ 97$ billion in these months, but several banks switched from other

\footnotetext{
${ }^{16}$ For an alternative counterfactual, we refer to Benati (2014). In his discussion of our paper, he shows that a more subdued balance sheet response to financial stress during the sample period (by shrinking the parameters of the balance sheet response to the CISS indicator) would have resulted in much more macroeconomic volatility.

${ }^{17}$ Notice that we do not consider the one-year LTROs of October 2009. The volume of these operations was $€ 75$ billion, but there was a net decline of total assets in this month due to a substantial reduction in other types of lending by the banking sector (partly because of improved macroeconomic conditions as a consequence of the June LTRO).
} 
types of lending (e.g., MROs or three-month LTROs) to the one-year LTROs. This can also be seen in figure 1. In sum, for the first counterfactual scenario, we shock the balance sheet in total by roughly $€ 341$ billion between the summers of 2009 and 2010. In a similar way, for the second counterfactual, we shock the balance sheet by $€ 316$ billion in December 2011, and by €272 billion in March 2012, i.e., $€ 588$ billion in total. Again, this is the net increase in total assets observed in both months, which is considerably less than the actual volume of €1,019 billion in three-year LTROs allocated by the ECB.

The results of both counterfactuals implied by the VAR model are shown in, respectively, figures 7 and 8 . The figures reveal that the macro consequences have been substantial. For the first counterfactual, we observe that the recovery in economic activity of 2010 would have been much more sluggish without the one-year LTROs and purchases of covered bonds. In particular, economic activity would have been roughly 0.6 percent lower in the summer of 2010 . Also, the pickup of inflation would have been much more subdued, with a persistent deviation from target. Furthermore, economic and financial stress (the CISS indicator) would have been a great deal higher, while the pickup of bank lending would have been much slower without the non-standard monetary policy measures taken by the ECB.

A similar story emerges for the three-year LTROs counterfactuals. Real GDP would have been approximately 1.2 percent lower in 2012 without the programs, i.e., a much deeper recession than the one we observed, while inflation would have been about 1.3 percentage points lower. Also noticeable is the strong collapse of bank lending without the three-year LTROs, while the policy rate would have hit the zero lower bound already in 2012.

Perhaps most striking for both counterfactuals is the fact that the ultimate expansion of the balance sheet would have been more or less the same without the extraordinary policy measures. This can be explained by the worse macroeconomic and financial conditions in the absence of the measures. More specifically, according to the estimated parameters of the VAR model, the lower level of economic activity and higher stress on financial markets would have resulted in an endogenous rise of the balance sheet of the ECB. The endogenous rise of the balance sheet is essentially the consequence of an increased dependence of banks on the ECB for their liquidity needs 
Figure 7. Counterfactual Evolution of Macroeconomic Aggregates without Implementation of One-Year LTROs and CBPP1
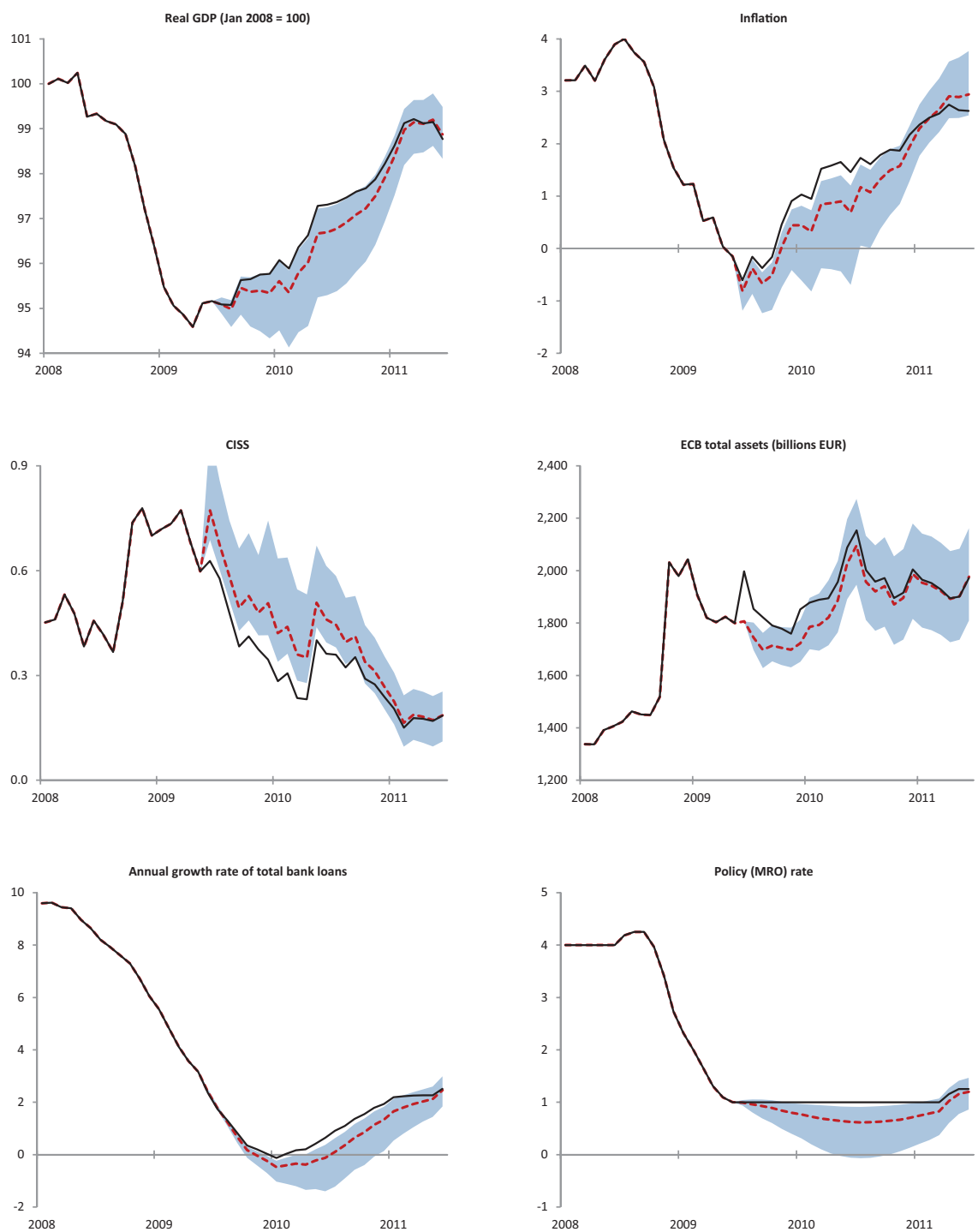

actual evolution $\quad$ - - - counterfactual implied by VAR (median, 16th and 84th percentiles of posterior distribution) 
Figure 8. Counterfactual Evolution of Macroeconomic Aggregates without Implementation of Three-Year LTROs
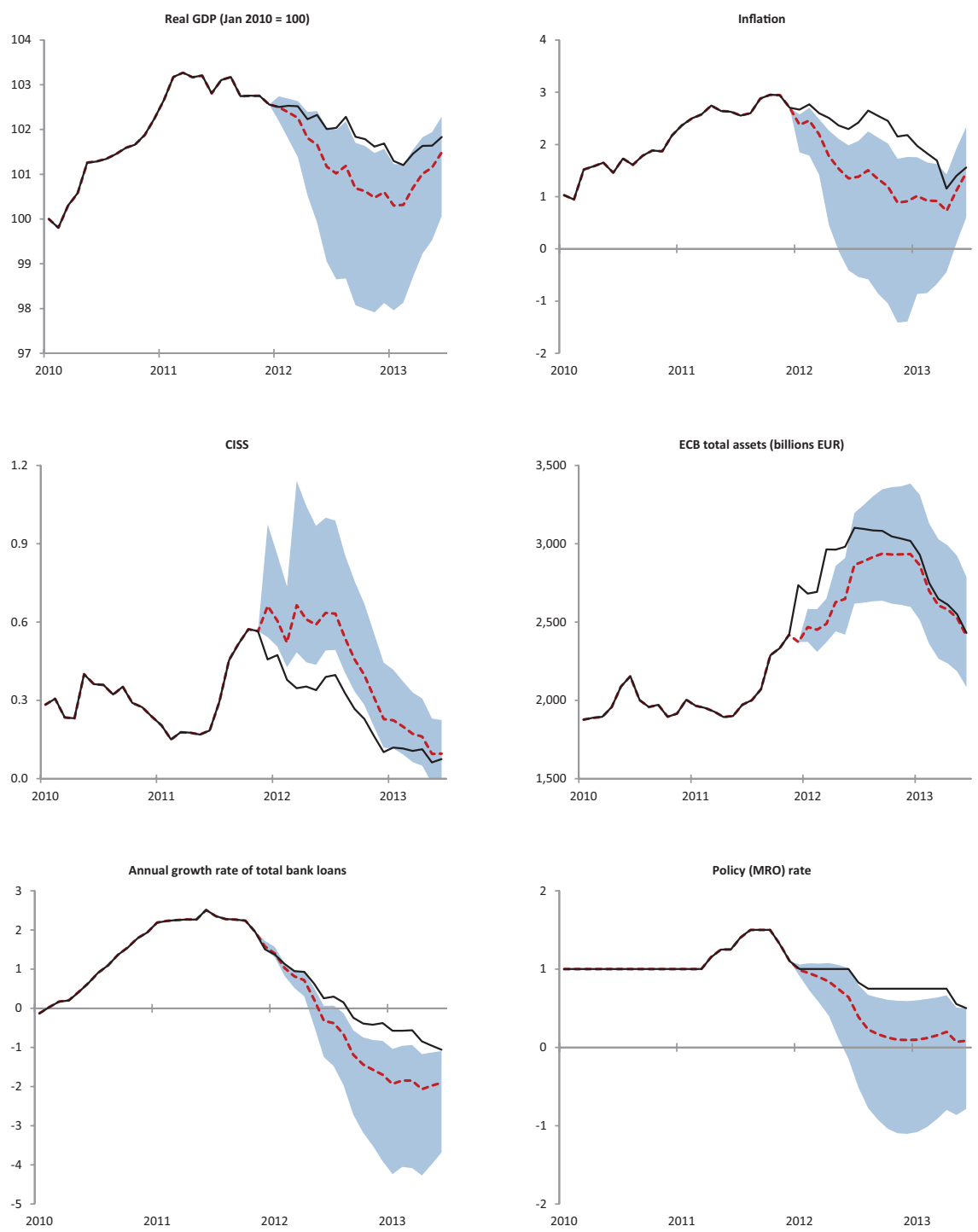

- 
in the context of the FRFA policy, in combination with the average reaction function of the balance sheet to the macroeconomic and financial market conditions during the sample period. This finding suggests that it is important for central banks to act preemptively, i.e., the macroeconomic outcome is then much better for a similar (ex post) balance sheet expansion.

\section{The Effects across Euro-Area Countries}

It may be useful to also analyze how individual euro-area countries are affected by the balance sheet shocks. For that purpose, we include output and consumer prices of each individual country in the $Z$-block of the near-VAR presented in section 518 The effects on economic activity turn out to be quite diverse. Figure 9 shows that the effects of a central bank balance sheet shock on output are relatively large in Germany, Austria, Finland, Estonia, Ireland, and Luxembourg. The effects are more subdued in France, Italy, Austria, Belgium, and the Slovak Republic. The estimations further show that the impact of the unconventional monetary policy measures of the ECB were negligible in Spain, the Netherlands, Portugal, Slovenia, and Cyprus. For Greece, we even find a puzzling negative response of output to a balance sheet expansion. On the other hand, as shown in figure 10, the effects on consumer prices are much more similar across countries. Hence, there is little evidence that in countries where output reacts more (less), inflation also reacts more (less). An explanation for such a different Phillips-curve type relationship across countries is not straightforward and would need additional analysis, but this is beyond the scope of this paper.

Since the peripheral countries of the euro area participated relatively more in the non-standard monetary policy actions of the ECB, the finding that the effects of expansionary (and restrictive) central bank balance sheet shocks turn out to be stronger in countries that

\footnotetext{
${ }^{18}$ Since individual countries are part of the euro-area aggregate, it is not necessary to allow for feedback of the individual countries on the euro-area variables. We can thus again use a block-diagonal VAR system, which ensures that the dynamics of the euro-area variables are invariant to the inclusion of the individual country variables, allowing for a comparison across countries (see also Peersman and Smets 2003).
} 


\section{Figure 9. Impact of Balance Sheet Shocks on Output in Individual Member Countries}
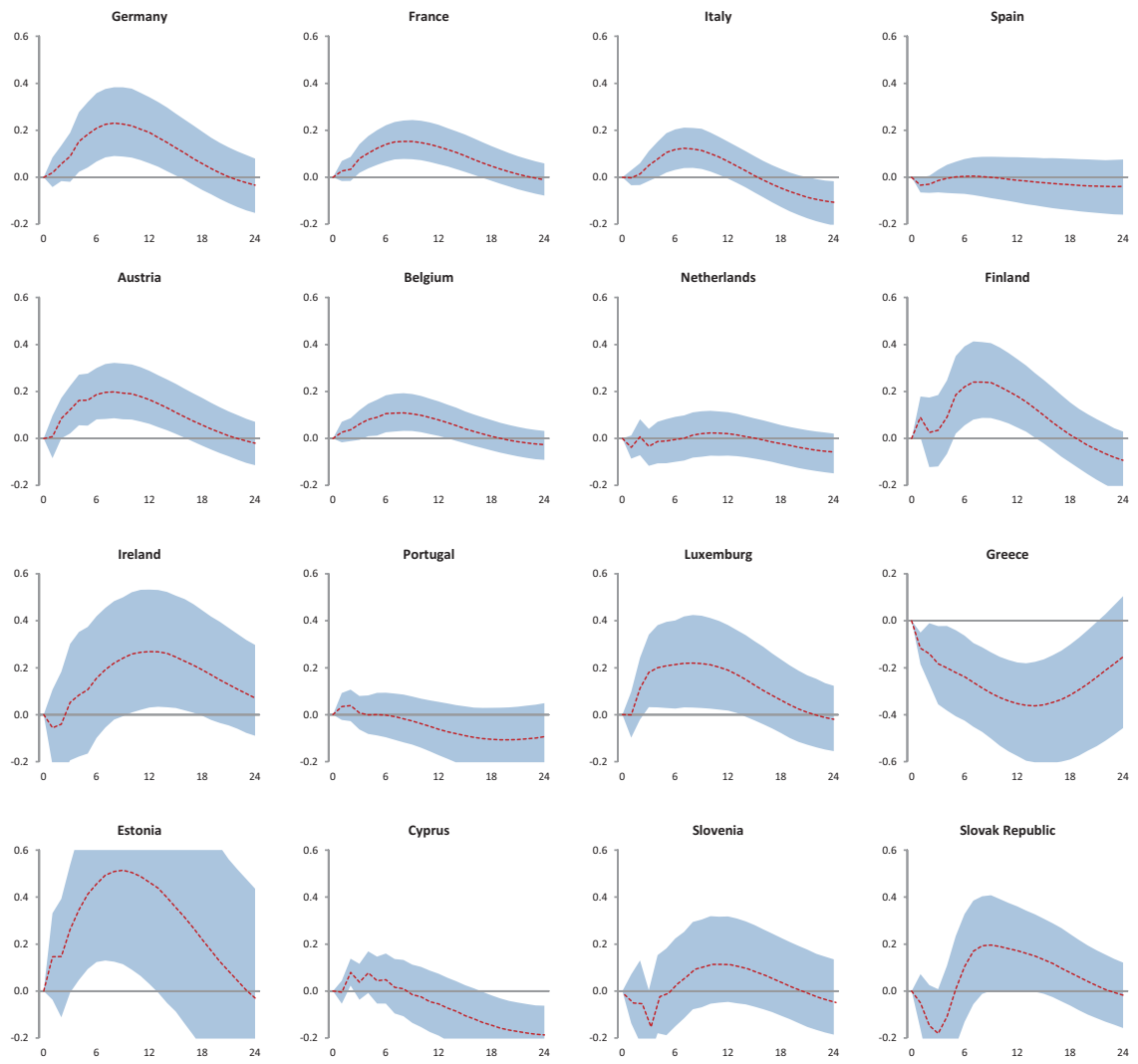

Note: Figures show median responses, together with 16 th and 84 th percentiles of the posterior distribution; horizon is monthly.

are generally less affected by the financial crisis is striking. A potential explanation is that a lot of banks in peripheral countries have not been able to convert the extra liquidity into more lending to the private sector because of their financial fragility and low capitalization. In particular, it is difficult for banks to increase lending supply if they are capital constrained. Accordingly, the macroeconomic effects of the balance sheet policies could be more subdued in countries where banks are on average less capitalized. This conjecture is supported 


\section{Figure 10. Impact of Balance Sheet Shocks on Consumer Prices in Individual Member Countries}
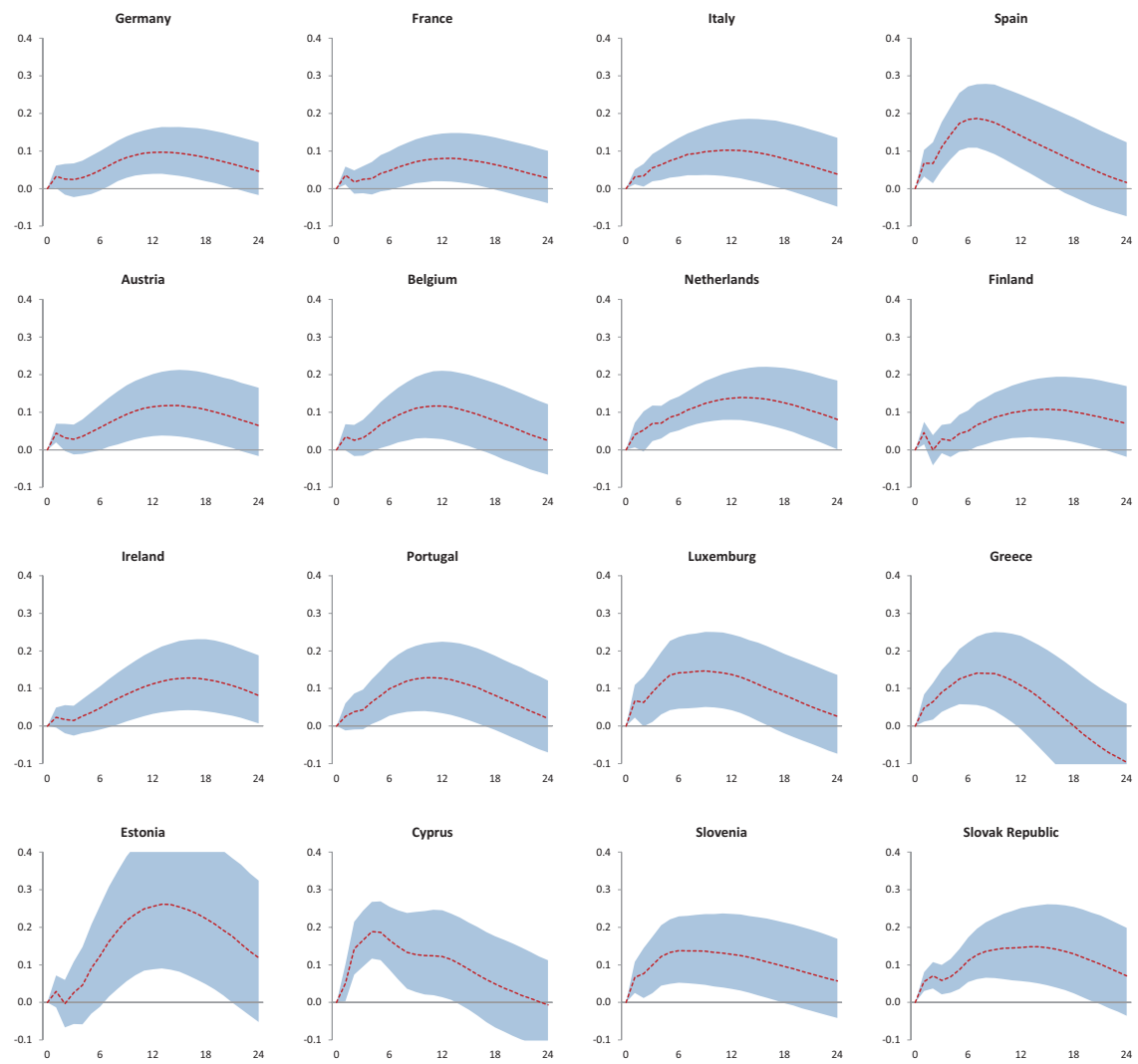

Note: Figures show median responses, together with 16 th and 84th percentiles of the posterior distribution; horizon is monthly.

by the data shown in figure 11 . The figure plots the correlation between bank capital and the estimated effects of the balance sheet shocks on output across individual countries. Given that correlation does not mean causation, we have to be careful when interpreting the results, but they are nevertheless informative about a potential relationship. More specifically, there is a strong positive correlation (0.73) between the (maximum) impact of an innovation to the ECB's balance sheet on economic activity in an individual country and the 


\section{Figure 11. Bank Capital and the Effects of Balance Sheet Shocks on Output in Euro-Area Countries}

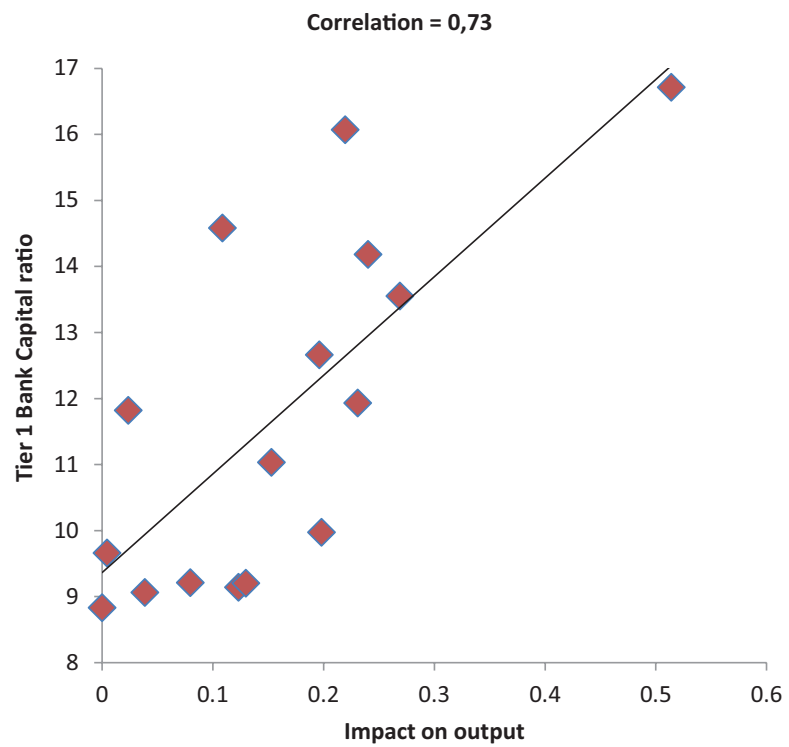

Note: The figure shows the correlation between tier 1 capital ratio of the national banking sector (average over sample) and the maximum effect of balance sheet shocks (median impulse responses) on output in the respective member country.

average tier 1 capital ratio of the respective consolidated national banking system over the sample period. In other words, the transmission of central bank liquidity support to the real economy seems to be linked to the solvency of the banking system. If the central bank injects liquidity but banks are not able or willing to lend to households and firms because of their own financial fragility, the effects on economic activity are more subdued. As a consequence, countries with a weakly capitalized banking system also react less to the unconventional monetary policies of the ECB.

\section{Conclusion}

In this paper, we have analyzed the effectiveness and transmission of the ECB's unconventional monetary policies since the onset of 
the financial crisis. Within an SVAR framework, we have identified exogenous innovations to the central bank balance sheet for a given policy rate, and estimated the dynamic effects on the macroeconomy. We find that euro-area output and consumer prices rise after an increase in the balance sheet of the ECB. The effects are qualitatively very similar to the impact of conventional monetary policy, in particular the output effects. This confirms that unconventional monetary policy actions that influence the size of the central bank balance sheet can be effective at stabilizing the economy. Our identification scheme, however, does not allow us to distinguish the effects of different types of balance sheet expansion - for example, lending operations versus outright purchases. This is a first avenue for future research.

Financial market and bank lending variables also react significantly to central bank balance sheet disturbances. We find that equity prices, lending volumes, and broad money rise after an expansionary balance sheet shock, whereas the intra-euro-area sovereign bond spread vis-à-vis Germany, bank lending rates, bank CDSs, and money-market rates fall. Financial markets and banks are thus important in passing on ECB unconventional monetary policy to the real economy. Based on survey responses of banks about their lending standards, we can conclude that the increase in bank lending coincides with a loosening of lending standards, and not so much with an increase in loan demand.

Counterfactual simulations show that the ECB's balance sheet measures have shielded the euro area from much worse macroeconomic outcomes. Interestingly, even in the worse macroeconomic scenario, the balance sheet would have increased by a similar amount. This would not have been because of a proactive use of the balance sheet by the central bank but rather because of increased demand due to lower economic growth and more financial stress. A similar balance sheet expansion can therefore go hand in hand with markedly different macroeconomic outcomes.

The identified unconventional monetary policy shock seems to affect euro-area countries differently. Specifically, output reacts more in countries that have been less affected by the financial crisis. The differential reaction of output across countries turns out to be strongly correlated with the degree of capitalization of the national banking sector. Output increases more in countries with a relatively 
better capitalized banking sector. This seems to underscore the importance of capitalization of the banking sector in transmitting unconventional monetary policy to the real economy. Whether this is indeed the case is another interesting avenue for future research.

\section{References}

Acharya, V., and S. Steffen. 2015. "The 'Greatest' Carry Trade Ever? Understanding Eurozone Bank Risks." Journal of Financial Economics 115 (2): 215-36.

Affinito, M. 2013. "Central Bank Refinancing, Interbank Markets, and the Hypothesis of Liquidity Hoarding. Evidence from a EuroArea Banking System." ECB Working Paper No. 1607.

Arias, J. E., J. F. Rubio-Ramirez, and D. F. Waggoner. 2014. "Inference Based on SVARs Identified with Sign and Zero Restrictions: Theory and Applications." Working Paper No. 2014-1, Federal Reserve Bank of Atlanta.

Benati, L. 2014. "Discussion of 'Effectiveness and Transmission of the ECB's Balance Sheet Policies'." ECB Workshop on Non-standard Monetary Policy Measures, European Central Bank, Frankfurt-am-Main, October 6.

Bernanke, B., and A. Blinder. 1988. "Credit, Money, and Aggregate Demand." American Economic Review 78 (2): 435-39.

- 1992. "The Federal Funds Rate and the Channels of Monetary Transmission." American Economic Review 82 (4): 901-21. Bernanke, B. S., and I. Mihov. 1998. "Measuring Monetary Policy." Quarterly Journal of Economics 113 (3): 869-902.

Cahn, C., J. Matheron, and J.-G. Sahuc. 2014. "Assessing the Macroeconomic Effects of LTROs." Working Paper No. 528, Banque de France.

Christiano, L., M. Eichenbaum, and C. Evans. 1999. "Monetary Policy Shocks: What Have We Learned and to What End?" Handbook of Macroeconomics, Vol. 1A, ed. J. B. Taylor and M. Woodford, 65-148 (chapter 2). North Holland.

- 2005. "Nominal Rigidities and the Dynamic Effects of a Shock to Monetary Policy." Journal of Political Economy 113 (1): $1-45$. 
Ciccarelli, M., A. Maddaloni, and J.-L. Peydro. 2013. "Heterogeneous Transmission Mechanism: Monetary Policy and Financial Fragility in the Eurozone." Economic Policy 28 (75): 459-512.

Curdia, V., and M. Woodford. 2011. "The Central-Bank Balance Sheet as an Instrument of Monetary Policy." Journal of Monetary Economics 58 (1): 54-79.

European Central Bank. 2013a. "Early Repayment of Funds Raised through Three-year Longer-term Refinancing Operations: Economic Rationale and Impact on the Money Market." Monthly Bulletin (February): Box 3, p. 31.

. 2013b. "Stylised Facts of Money and Credit over the Business Cycle." Monthly Bulletin (October): Box 1, p. 18.

Fahr, S., R. Motto R., M. Mostagno, F. Smets, and O. Tristani. 2013. "A Monetary Policy Strategy in Good and Bad Times: Lessons from the Recent Past." Economic Policy 28 (74): 243-88.

Gambacorta, L., B. Hofmann, and G. Peersman. 2014. "The Effectiveness of Unconventional Monetary Policy at the Zero Lower Bound: A Cross-Country Analysis." Journal of Money, Credit and Banking 46 (4): 615-42.

Gertler, M., and P. Karadi. 2011. "A Model of Unconventional Monetary Policy." Journal of Monetary Economics 58 (1): 17-34.

Giannone, D., M. Lenza, H. Pill, and L. Reichlin. 2012. "The ECB and the Interbank Market." Economic Journal 122 (564): F467F486.

Holló, D., M. Kremer, and M. Lo Duca. 2012. "CISS - A Composite Indicator of Systemic Stress in the Financial System." ECB Working Paper No. 1426.

Kashyap, A., and J. Stein. 1995. "The Impact of Monetary Policy on Bank Balance Sheets." Carnegie-Rochester Conference Series on Public Policy 42 (1): 151-95.

Lenza, M., H. Pill, and L. Reichlin. 2010. "Monetary Policy in Exceptional Times." Economic Policy 25 (62): 295-339.

Peersman, G. 2005. "What Caused the Early Millennium Slowdown? Evidence Based on Vector Autoregressions." Journal of Applied Econometrics 20 (2): 185-207.

- 2011. "Macroeconomic Effects of Unconventional Monetary Policy in the Euro Area." ECB Working Paper No. 1397.

Peersman, G., and F. Smets. 2003. "The Monetary Transmission Mechanism in the Euro Area: More Evidence from VAR 
Analysis." In Monetary Policy Transmission in the Euro Area, ed. I. Angeloni, A. Kashyap, and B. Mojon, 36-55 (chapter 2). Cambridge University Press.

Sims, C., J. Stock, and M. Watson. 1990. "Inference in Linear Time Series Models with Some Unit Roots." Econometrica 58 (1): 113-44.

Smets, F., and R. Wouters. 2007. "Shocks and Frictions in US Business Cycles: A Bayesian DSGE Approach." American Economic Review 97 (3): 586-606.

Uhlig, H. 2005. "What Are the Effects of Monetary Policy on Output? Results from an Agnostic Identification Procedure." Journal of Monetary Economics 52 (2): 381-419. 